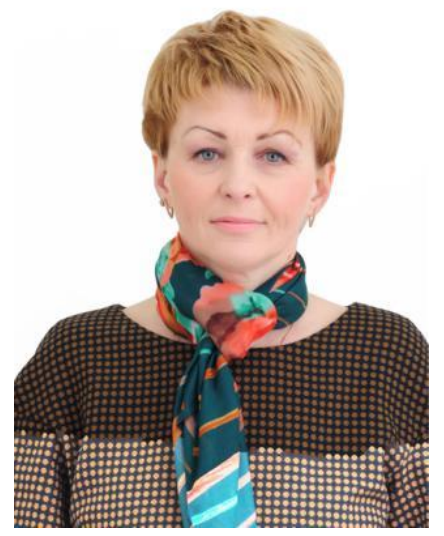

\section{Любов Прокопів,}

кандидат педагогічних наук, доцент кафедри

педагогіки імені Богдана Ступарика, ДВНЗ

«Прикарпатський національний університет

імені Василя Стефаника» (м. Івано-Франківськ,

Україна)

\author{
Liubov Prokopiv, \\ $\mathrm{PhD}$ in Education, Associate Professor, \\ Department of Pedagogy, \\ Vasyl Stefanyk Prekarpation National University \\ (Ivano-Frankivsk, Ukraine) \\ prk1@i.ua \\ ORCID ID 0000-0001-8661-510X
}

\title{
FEATURES OF USING METHODS AND FORMS OF THE TEACHING ORGANIZATION IN A SMALL SCHOOL (2ND HALF OF 20TH CENTURY) AND THEIR IMPROVEMENT IN MODERN CONDITIONS
}

Abstract. This article is about methods and forms of organization of training in a small school. The problem is actualized in the context of the adopted strategy for modernizing general secondary education, namely the Concept of the New Ukrainian School, in accordance with which the restructuring of the educational sector is being carried out in the rural areas as well. The purpose of the article is to identify features of using methods and forms of teaching organization in a small school (2nd half of the 20th century) and effective methods and forms of teaching organization at the present stage. The article has the following tasks: to describe the methods of teaching organization in a small school in accordance with the selected stages; to specify the basic forms of teaching organization in small schools of the studied period; to identify the effective aspects of implementing the partnership pedagogy in the Carpathian educational space.

In order tosolve the research tasks, the following theoretical methods were used: analysis and systematization of psychologic al, pedagogical and methodical literature; analysis of archival, sources sociological surveys, questionnaires and interviews

The author conducted questionnaires, surveys and interviews confirmed the effectiveness of the innovative teaching methods selected for implementation in the operation of a small school.

Keywords: small school, small rural schools, under-subscribed school forms and methods of teaching, historical stages.

\section{ОСОБЛИВОСТІ ВИКОРИСТАННЯ МЕТОДІВ І ФОРМ ОРГАНІЗАЦІЇ НАВЧАННЯ В МАЛОКОМПЛЕКТНІЙ ШКОЛІ (ДРУГА ПОЛОВИНА ХХ СТ.) ТА ЇХ УДОСКОНАЛЕННЯ В СУЧАСНИХ УМОВАХ}

Анотація. У статті автор розкриває актуальні питання пошуку не лише нових типів навчання, аі форм, методів навчальної діяльності. Проблема використання різноманіттнх методів і форм організації навчання актуалізується у контексті Концепції Нової української школи. Метою статті є виявити особливості використання методів і фрорм організації навчання у малокомплектній школі (друга половина XX cт) та результативні методи та форми організації навчання на сучасному етапі.

Автор ставить перед собою завдання охарактеризувати відповідно до виділених етапів методи організації навчання у малокомплетній школі; уточнити основні форми організації навчання у малокомплектних школах досліджуваного періоду; виявити результативні аспекти впровадження методів і форм навчання у малокомплектній школі.

Для розв'язання завдань дослідження використано теоретичні методи: аналіз і систематизація психолого-педагогічної і навчально-методичної літератури, аналіз архівних джерел, метод педагогічної реконструкції, який надає можливості відтворити педагогічні реалії впровадження методів і форм організації навчання у малокомплетних школах; соціологічні дослідження, анкетування та інтерв'ю та ін.

Устатті у відповідно до виділених історичних етапів визначено основні основних методів навчання у малокомплектних школах. На першому визначеному нами етапі в (1945 - 1958 рр. ) -це традиційні методи організації навчання ( бесіди, пояснення, самостійна робота тощо). На етапі кількісного збільшення малокомплектних(малочисельних) шкіл (1958- 1985 pp.) - урізноманітнювались методи організації навчання. Поширеними були «лабораторні завдання, домашні роботи учнів, літні завдання, позакласне читання, робота в живому куточку, методи самостійної роботи з учнями. У період з 1985 - 1991 р. - поширеними були диференційовані методи навчання, хоча і традиційне навчання мало свої переваги. На етапі 1991-2000 pp. - малочисельна школа у незалежній Україні, неабиякого розголосу набували інтерактивні методи навчання, пошук інноваційного навчання.

Щодо форм організації навчання, то на всі виділених нами етапах автор традиційним визначає урок. На початку 90-х рр. XX ст особлива увага надавалась індивідуальному та кооперативному навчанню. 
Проведені автором анкетування, опитування та інтерв'ю підтвердили результативність обраних інноваційних методів навчання у практику роботи малочисельної школи. Кількість респондентів, що вбачали позитивні результати від впровадження інноваційних методів навчання збільшилося. Реалізація вище визначених тезисів дала можливість прийти до висновку про потребу заміни традиційної урочної фрорми організації навчання на групові та індивідуальні, потребу впровадження у практику роботи такого типу шкіл інноваційних методів навчання (алгоритмізацію самостійної роботи учнів, ситуативне моделювання, колективне групове навчання); структурувати предметні курси на укрупнені дидактичні одиниці. Ключові слова: мала школа, малочисельна школа, малокомплектна школа, форми і методи навчання, історичні етапи.

\section{INTRODUCTION}

At the present stage of societal development, there is a problem of finding not only new teaching types, but also forms and methods of educational activity. However, the question arises whether the small schools are entitled to be preserved under conditions that require modernization, consolidation, etc. The Ukrainian legislation [5] promotes the search for innovative types of schools, among which there is space for small schools, including the private ones.

The problem is actualized in the context of the adopted strategy for modernizing general secondary education, namely the Concept of the New Ukrainian School, in accordance with which the restructuring of the educational sector is being carried out in the rural areas as well.

These issues are relevant in the context of searching for innovative teaching forms in conditions of individual and distance learning.

Our country is at the same stage as foreign education: the issue of preserving the best traditions of the existence of a modern school. The experience of European countries in this field is positive [13].

In this context, there is a need to study existing experience. This research continues the author's publication cycle [8]. AlM

AND TASKS RESEARCH. The purpose of the article is to identify features of using methods and forms of teaching organization in a small school (2nd half of the 20th century) and effective methods and forms of teaching

organization at the present stage.

The article has the following tasks:

1) to describe the methods of teaching organization in a small school in accordance with the selected stages;

2) to specify the basic forms of teaching organization in small schools of the studied period;

3) to identify the effective aspects of implementing the partnership pedagogy in the Carpathian educational space.

RESEARCH METHODS: In order to solve the research tasks, the following theoretical methods were used: analysis and systematization of psychological, pedagogical and methodical literature; analysis of archival sources which helped determine the state and theoretical substantiation of the use of methods and forms teaching organization in a small school; method of pedagogical reconstruction which provides the opportunity to recreate pedagogical realities of introducing methods and forms of teaching organization in small schools; sociological surveys, questionnaires and interviews with the participation of employees of small schools in Ivano-Frankivsk Oblast; presentation of the research results.

\section{RESEARCH RESULTS}

The features of using methods and forms of teaching organization in a small school will be analyzed according to the determined stages. Analysis of methods and forms of of teaching organization in this order allows asserting their diversity.

At the first stage (in 1945-1958), we find the restoration of operation of small schools, ideological pressure on the educational process. We would like to emphasize that at this stage, under the conditions of the functioning of a 4-year elementary school, the main task of a small school was to teach reading, writing and basic mathematics; however, the final tasks of a small school were not provided [6, p. 63].

The main form of teaching organization in a small school in this period was a lesson. It consisted of two clear components: working with students and independent work.

As our research showed, teachers used mostly frontal forms of work with children during lessons in a small school. Laboratory tasks and homework were common too.

At this time, particular attention was paid to the study of natural sciences. In small schools, «laboratory tasks, student's homework, summer assignments, work in a educational and research plot at school grounds, compilation of herbaria, collections, extra-curricular reading, work in a green corner» [3, p.109].

Among the teaching methods, traditional verbal methods (explanation, discussion, etc.) were used.

At the stage of quantitative increase of small (small-numbered) schools (1958-1985), methods and forms of teaching organization became more diversified.

Still, the main form of teaching organization was a lesson.

With the transition (in 1969) to 3-year elementary school, the teaching programs emphasized on the increase of the theoretical level of educational material; developmental and creative teaching methods were introduced in small schools [11].

As the source analysis shows, the methods and forms of teaching organization were directly linked to the Party's documents at that time («Provision on strengthening the connection of the school to everyday life and the further development of public education in the Ukrainian SSR» [2; 1, arch. 23]. On the one hand, they demanded a radical change in the state of the educational process; on the other hand, it was only a formal aspect.

The choice of methods and forms of teaching organization was influenced by the tasks of Perestroika, which consisted in the practical orientation of the forms of teaching organization. 
According to requirements, teaching must be accompanied by visual aids. In addition to the lesson, there were also independent experiments, laboratory works, group practicals, educational excursions; training was also combined with work in school workshops, basic agricultural households, factories, plants and educational and research plot at school grounds [3, p.110].

At that time, teaching programs for general education schools were changed in Ukraine almost annually. It also affected the features of the forms of teaching organization in small schools.

The main emphasis in the programs of general educational disciplines was placed on the improvement of methods of students' independent work. For example, the Natural Science lessons implied «independent observation of the development of plants. The most common methods were working with didactic handout material, textbooks, compiling herbariums and various collections, etc.» [7].

As evidenced by the archive materials of the Central State Archives of Higher Authorities, the archives of Odessa, Kharkiv Oblast, etc., as well as confirmed by former students of the small schools of Ivano-Frankivsk Oblast, the methodology of teaching the subjects in small schools was subordinated to certain educational methodical manuals and was mandatory for use [12, arch. 106; 1, arch. 23].

The analysis of archives and results of educational activities of students (school journals, student notes, etc.) of small schools of Ivano-Frankivsk (Hryniv school) and Kharkiv (Stepankivka primary school, Sorokivka eight-year school) Oblasts proves, on the one hand, the use of traditional (verbal, visual, practical) teaching methods.

We must emphasize that there were clearly distinguished methods of independent work with students in small schools at this time.

Even at the time of totalitarianism, the practical operation of small schools involved the methods of teaching organization aimed at developing observation, independence and initiative of students, and instilling skills of independent work [10, p. 37].

Each of the methods was clearly defined and analyzed, presented in a certain order. A comparative analysis of the methods of independent work at the lessons of the Natural and Humanitarian Cycle is given in Table 1.

Table 1.

\section{The comparative analysis of the methods of independent work in small school for primary school students}

\begin{tabular}{|l|l|}
\hline Lessons from Natural Cycle & Lessons from Humanitarian Cycle \\
\hline observing plants & independent work with the book \\
\hline $\begin{array}{l}\text { conducting educational experi- } \\
\text { ments for the study of plant life }\end{array}$ & independent retelling of educational material \\
\hline $\begin{array}{l}\text { research work on the cultivation of } \\
\text { agricultural plants }\end{array}$ & working on essays \\
\hline working with books and handouts & independent reading \\
\hline
\end{tabular}

Source [9].

In a small school, the methods of independent work were divided according to the constituents of a lesson:

1) independent work during explanation of new material: «The student performs independent work which prepares him for a deeper perception and learning of new material taught by teacher: conducts preliminary observations, simple experiments, reads a certain text. Students can perform independent work during the presentation of material by teacher: compile a table or a diagram according to the teacher's presentation, take notes» [3, p.7].

2) independent work after the presentation of material: students have independently studied the text from the textbook, answered the questions after the text, conducted observations, solved the tasks, etc. The characteristic of such independent tasks was specification, justification of the Statements said.

3) independent work without preliminary presentation of material by teacher, independent work using literary sources. Such an independent work implied the acquisition of knowledge from observations or experiments, the search for new statements, the development of ability to work independently, draw conclusions, etc.

Such a division, in our opinion, contributed to the precise planning of both independent work and lessons.

These forms of teaching organization were widespread at the stage of formation and development of a small school within the framework of «Perestroika» (1985-1991).

The method of independent work had its own features in this period in a small school, namely observance of the goal of learning, preference of individual forms.

At that time, there were a three-year and four-year elementary school; there were some changes, a group work was introduced in the practical operation of a small school, differentiated education became fashionable.

At the stage of 1991-2000, a small school operated in independent Ukraine, individual work with students, distance learning forms have been widely disseminated.

In a small school, this work was almost at the foreground. O. Pinskyi notes that when working on the task individually, the student is not bound to the class or to members of a temporary or permanent group and advances in the process 
of performing independent work at his own pace. Execution of such tasks requires from him his own effort, showing his independence, requires perseverance, diligence, ability to concentrate on performing the tasks [3, p.114].

The survey conducted in the 1990s by O. Pinskyi among Biology teachers in rural small schools in Kharkiv and Velykuroburlutsk districts of Kharkiv Oblast showed a higher percentage and better efficiency in the organization of individual independent work than group and frontal work. Such an advantage of individual forms of work is explained by a definite and clear selection.

We conducted a survey of teachers from small schools in Ivano-Frankivsk and Chernihiv Oblasts (about 15 schools) who indicate that today the individual and independent work of students is also more effective than the frontal one.

In the opinion of teachers, its success was determined by the correct selection of tasks, the systematic control of its execution by teacher, the provision of timely advisory assistance in case of need from students. We believe that at the present stage of development of the school, taking into account the distance learning form or internet learning, independent work becomes more relevant.

Today, the benefits of individual work are obvious. Firstly, the student can work at his own pace, and secondly, he can be a member of both a permanent and a temporary group and work at his individual pace; thirdly, students develop the ability of self-perfection in the conditions of independent work.

Among the disadvantages, we define the lack of communication between students in a class.

At the current stage of development of small schools, special attention is needed by counselor teachers and their ability to cooperate with their students.

In 1991-2000, frontal independent work was widespread (both in Natural Science and Humanitarian profiles).

The advantage of such teaching methods lies in encouraging students from small schools to collaborate.

In this context, we will analyze the common and distinct characteristics between frontal independent work and frontal discussion (Table 2).

Table 2

Features of the organization of frontal work in a small school

\begin{tabular}{|c|c|}
\hline $\begin{array}{l}\text { Features of the organization } \\
\text { of frontal independent work }\end{array}$ & $\begin{array}{l}\text { Features of the organization } \\
\text { of frontal discussion }\end{array}$ \\
\hline \multicolumn{2}{|c|}{ Goal: solving the learning problem with the joint efforts of teacher and students. } \\
\hline Getting instruction in the form of a table & Getting instruction in the form of questions and answers \\
\hline $\begin{array}{l}\text { Each student performs tasks independently, indi- } \\
\text { vidually, with his own efforts }\end{array}$ & $\begin{array}{l}\text { Everyone does the tasks, but answer only individual } \\
\text { questions }\end{array}$ \\
\hline The whole class is involved & $\begin{array}{l}\text { Each student answers one or more questions, part of } \\
\text { the class remains overlooked }\end{array}$ \\
\hline $\begin{array}{l}\text { Types of independent work: } \\
\text { independent full or partial reproduction of the } \\
\text { material; } \\
\text { tasks on the ability to highlight the main point; } \\
\text { tasks for illustrating theoretical assumptions, rules } \\
\text { using practical examples; } \\
\text { independent works - written answers to questions } \\
\text { on the studied material; independent works on } \\
\text { establishing the connection of the studied material } \\
\text { with the previous one. }\end{array}$ & $\begin{array}{l}\text { Types of frontal discussions: } \\
\text { answers to questions on topics that imply full reproduc- } \\
\text { tion of the material; } \\
\text { discussion of life challenges; } \\
\text { frontal stimulating discussions with searching for an- } \\
\text { swers; } \\
\text { discussions about evaluation of speech phenomenon; } \\
\text { discussions at the stage of actualization of background } \\
\text { knowledge. }\end{array}$ \\
\hline
\end{tabular}

As can be seen from the table, it is the independent work that contributed to the development of speech skills. The analysis of class journals has confirmed the attention to independent works. They develop attention, analytical, thoughtfulness, observation of students. All this supported not only the systematization of knowledge of students in a small school, but also improved methods of conducting classes by teachers, contributed to the organization of school research, which corresponded with the current social order, the needs of that time.

At the beginning of the 21 st century, in contrast to the frontal teaching methods, cooperative education was disseminated in small schools as a «teaching organization of students gathered in small groups united by the general educational purpose» [4, p.14].

The following possibilities of cooperative teaching in small schools were defined:

- the involvement of all students at any stage of the lesson;

- opportunity to speak, express oneself, develop the speech skills;

- opportunity of mutual teaching;

- ability to perform various social roles;

- a real opportunity to acquire skills of self-organization, fast adaptation to the collective;

- development of mutual assistance, mutual support [4, p.14]. 
The basis of cooperative teaching in small schools includespairs, groups.

O. Pometune notes, that «work in pairs is used both as a separate independent teaching technology and a preparatory stage for group work that helps develop communicative skills and abilities in students» [4, p.14].

Among the main methods of cooperative teaching that were used in small schools today, the following ones were common: work in small groups, pairs, threes, «rotational threes», «aquarium», «carousel», «jigsaw», etc.

The example of using cooperative teaching in small groups can be the method of «Synthesis of Thoughts», which involves finding consistent thoughts, conducting a dialogue, it excludes opposition. At the first stage, students are divided into groups. After division into groups, students do not describe the work on the board, but pass their thoughts to the following groups that continue their ideas, emphasize what they disagree with. The works are subjected to the analysis by experts who make a general report. It is discussed by the class.

Another method of cooperative education that is common in small schools is «Joint Project». Each group receives its tasks, which create a joint project when performed.

On the basis of the work done with the workers of small schools, we introduced both traditional and innovative methods of teaching into the practice of the school's operation in 5 schools of 5 districts of Ukraine in the Ivano-Frankivsk region (Verkhovyna district, Velykyi Khodak village, Dolynsky district, Myslivka village, Kosiv district, Richka village, Rogatyn district, Nyzhnia Lypytsia village, Yaremche city, Voronenko village). In total, 3745 people live in the listed settlements (as of 01.04.2017). Number of employees of small schools stands at 112; students - 363; classes - 30 . The results of the most used methods and forms of teaching organization are shown in the figure 1.

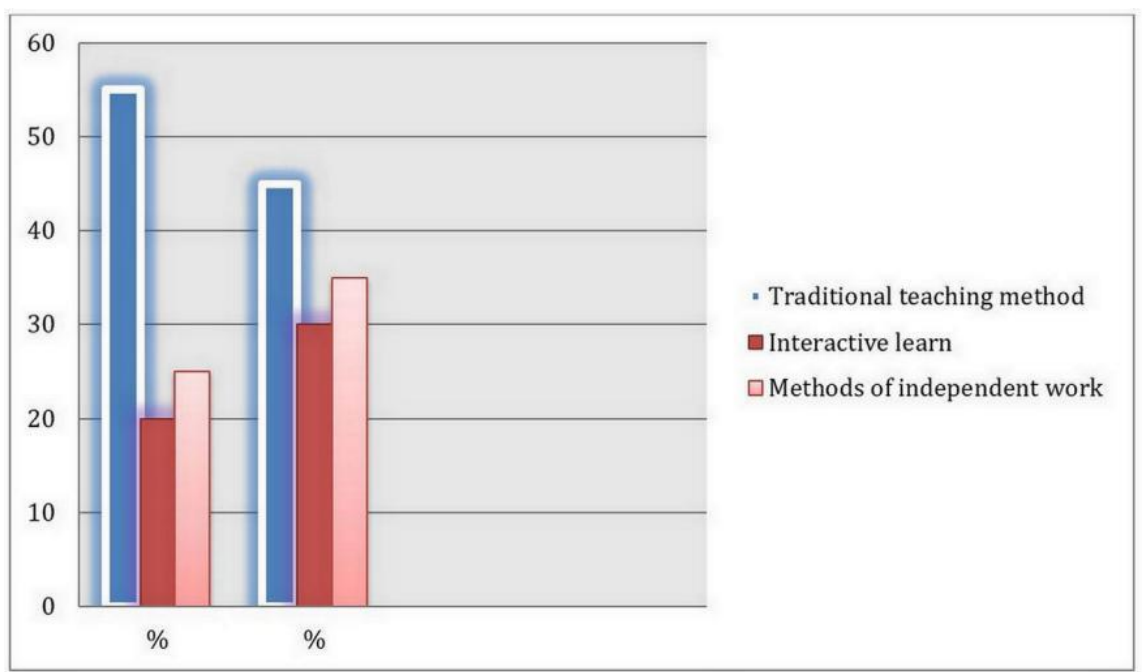

Fig. 1. Indicators of the use of teaching methods in small schools of the Carpathian educational space.

As can be seen from the diagram, innovative methods are currently relevant (distance learning, methods of information learning, etc.), although a significant place still belongs to independent work.

The generalization of these indicators shows that as a result of the study, not only the understanding of the problem increases, but also the need of improvement of the work of teachers in the field of teaching methods.

Consequently, a conducted study on the implementation of modern methods and forms of teaching organization in small schools has allowed to identify positive dynamics. The obtained data coincide with the data of researchers of small schools, schools of the Carpathian region. At the same time, on the other hand, contemporary science and pedagogical practice just started the introduction of the concept of a new Ukrainian school, including the use of innovative teaching technologies. Therefore, we expect further development of this topic.

\section{CONCUSSION AND PROSPECTS FOR FURTHER RESEARCH}

The small school in its historical aspect has the right to exist and preserve traditions along with the emergence of new teaching methods and forms.

According to the historical stages we have identified, the following basic methods of learning iwere defined: during the first stage we identified, in 1945-1958, traditional methods of organizing learning (discussions, explanations, independent work, etc.) the most common. At the stage of quantitative increase of small (small-numbered) schools (1958-1985), teaching methods and organization were diversified. In small schools, laboratory tasks, student's homework, summer assignments, work in a educational and research plot at school grounds, compilation of herbaria, collections, extra-curricular reading, work in a green corner were commonplace. Methods of independent work with students have diversified at this time. Between 1985 and 1991, differentiated teaching methods were used, although traditional teaching had its own advantages. At the stage of 1991-2000, interactive teaching methods, searching for innovative learning received a fair amount of publicity in a small school in independent Ukraine.

Regarding the forms of teaching organization, a lesson was traditional for all the stages that were defined by us; in the early 1990s, special attention was given to individual and cooperative learning. 
Our questionnaires, surveys and interviews confirmed the effectiveness of the innovative teaching methods selected for implementation in the operation of a small school. The number of respondents who saw positive results from the introduction of innovative teaching methods increased, which made it possible to reach a conclusion on the prospects of this direction of work. The implementation of the above-stated theses has made it possible to come to the conclusion that there is a need to replace the traditional lesson form of teaching organization with group and individual ones, the need to introduce innovative teaching methods into operation of this kind of schools (algorithmization of students' independent work, situational modeling, collective group training), and to structure subject courses into consolidated didactic units.

\section{СПИСОК ВИКОРИСТАНИХ ДЖЕРЕЛ}

[1] ДАХО. Фонд Р. 3858. оп.12. справа 1099 (Про заходи дальшого поліпшення роботи середньої загальноосвітньої школи в УРСР (1970)), арк. 23.

[2] Народное образование в СССР. Общеобразовательная школа. Сборник документов 1917-1973 гг. М.: Педагогика, 1974. 559 с.

[3] Пінський О. О. Самостійна робота учнів у процесі вивчення дисциплін природничого циклу в малокомплектних школах Слобожанщини (60-90 рр. XX ст.): : дис... канд. пед. наук: 13.00.01 / Харк. нац. пед. ун-т ім. Г. С. Сковороди. Харків, 2007. 248 с.

[4] Пометун О. Кооперативне навчання у малокомплектній школі. Сільська школа України. 2015, № 1 (109). С. 14-15.

[5] Про освіту: Закон України від 05.09.2017 р. №2145- VII. URL.: http://zakon3.rada.gov.ua/laws/show/2145-19.

[6] Програми початкової школи / ред. Н. О. Говядовська. Київ: Рад. школа, 1951. 70 с.

[7] Программы восьмилетней школы. Начальные классы 1-3. Москва: Просвещение, 1980. 208 с.

[8] Прокопів Л. Динаміка розвитку сільських малочисельних шкіл гірського регіону Івано-Франківщини (2000-2016р.). Гірська школа Українських Карпат. 2017. № 16. С. 160 - 165.

[9] Самостоятельная работа учащихся в малокомплектной школе / Под ред.

М.А. Мельникова, А.М.Пышкало. Москва: Педагогика, 1974. 200 с.

[10] Самостоятельные работы учащихся по биологии: Пособие для учителя / Е.П.Бруновт, А.Е. Богоявленская, Е.Т. Бровкина и др. Москва: Просвещение, 1984. 160 с.

[11] Сборник программ для средней общеобразовательной школы : пособие для руководителей органов нар. образования и шк. Ч. 1 / [ред. Ю. Ю. Иванов]. Москва: Просвещение, 1968. 432 с

[12] ЦДАВОВУ оп. 15, справа № 6422 (Навчальні плани шкіл республіки на 1967 - 1968 н.р., затверджений Міністерством освіти УРСР, арк. 106.

[13] Samel A. Relacja z zajęć o podatkach w Szkole Podstawowej w Łęgu Probostwie [Report on tax classes at the Primary School in Łęg Probostwa]. (n.d). URL: http:// /opolityce.ceo.org.pl/aktualnosci/relacja-z-zajec-o-podatkach-w-szkole-podstawowej-w-legu-probostwie [in Polish ].

\section{REFERENCES (TRANSLATED AND TRANSLITERATED)}

[1] DAXO. Fond R.-3858. op.12. sprava 1099. Pro zaxody` dal’shogo polipshennya roboty` seredn`oyi zagal`noosvitn`oyi shkoly` v URSR (1970). (On measures to further improve the work of secondary schools in the Ukrainian SSR), ark. 23. (in Ukrainian)

[2] Narodnoe obrazovany`e v SSSR(Folk education in the USSR). Obshheobrazovatel'naya shkola. Sborny`k dokumentov 1917-1973 gg. M.: Pedagogy`ka, 1974. 559 s. (in Russian)

[3] Pins`ky`j O. O. Samostijna robota uchniv u procesi vy`vchennya dy’scy`plin pry’rodny`chogo cy`klu $v$ malokomplektny`x shkolax Slobozhanshhy ny` (60-90 rr. XX st.) ( Dependent work of students in the process of studying the disciplines of the natural cycle in the small-scale schools of Slobozha:nshchyna (60-90 years of the XX century): dy`s... kand. ped. nauk: 13.00.01 / Xark. nacz. ped. un-t im. G. S. Skovorody'. Xarkiv, 2007. 248 s. (in Ukrainian)

[4] Pometun O. Kooperaty`vne navchannya u malokomplektnij shkoli (Co-op training in a small school). Sil's`ka shkola Ukrayiny’. 2015, № 1 (109). S14-15 (in Ukrainian)

[5] Pro osvitu (About education): Zakon Ukrayiny` vid 05.09.2017 r. \#2145- VII. URL.: http://zakon3.rada.gov.ua/laws/show/2145-19. (in Ukrainian)

[6] Programy` pochatkovoyi shkoly (Elementary School Programs)`' red. N. O. Govyadovs`ka. Ky`yiv: Rad. shkola, 1951. 70 s. (in Ukrainian)

[7] Programmы vos`my`letnej shkolы (Programs of the eight-year school). Nachal’nыe klassы 1-3. Moskva: Prosveshheny`e, 1980.208 s. (in Russian)

[8] Prokopiv L. Dy’namika rozvy`tku sil’s`ky`x malochy`sel’ny`x shkil girs`kogo regionu Ivano-Frankivshhy ny` (2000-2016 r.)(The dynamics of development of rural small schools of the mountain region of Ivano-Frankivsk region (2000-2016).). Girs`ka shkola Ukrayins `ky $x$ Karpat. 2017. № 16. S.160 165. (in Ukrainian)

[9] Samostoyatel'naya rabota uchashhy'xsya v malokomplektnoj shkole( Independent work of pupils in a small school) / Pod red. M.A.Mel'ny'kova, A.M.Pushkalo. Moskva: Pedagogy`ka, 1974. 200 s. (in Russian)

[10] Samostoyatel'nыe rabotы uchashhy`xsya po by`ology`y (Students' independent work on biology): Posoby`e dlya uchy`telya /E.P.Brunovt, A.E.Bogoyavlenskaya, E.T.Brovky`na y’ dr. Moskva: Prosveshheny`e, 1984. 160 s. (in Russian)

[11] Sborny`k programm dlya srednej obshheobrazovatel'noj shkolы (Collection of programs for secondary school ): posoby`e dlya rukovody`telej organov nar. obrazovany`ya y`shk. Ch. 1 / [red. Yu. Yu. Y`vanov]. Moskva: Prosveshheny`e, 1968. 432 s. (in Russian)

[12] CzDAVOVU op. 15, sprava № 6422 . Navchal'ni plany` shkil respubliky` na 1967 - 1968 n.r., zatverdzheny`j Ministerstvom osvity` URSR. (Educational plans of schools of the republic for 1967 - 1968, approved by the Ministry of Education of the USSR. the arch ) ark. 106/. (in Ukrainian)

[13] Samel A. Relacja z zajęć o podatkach w Szkole Podstawowej w Łęgu Probostwie(Report on tax classes at the Primary School in Łęg Probostwa). (n.d). URL: http:// /opolityce.ceo.org.pl/aktualnosci/relacja-z-zajec-o-podatkach-w-szkole-podstawowej-w-legu-probostwie. (in Polish) 